\title{
Proposal to transfer Halococcus turkmenicus, Halobacterium trapanicum JCM 9743 and strain GSL-11 to Haloterrigena turkmenica gen. nov., comb. nov.
}

\author{
Antonio Ventosa, ${ }^{1}$ M. Carmen Gutiérrez, ${ }^{1}$ Masahiro Kamekura ${ }^{2}$ \\ and Michael L. Dyall-Smith ${ }^{3}$
}

Author for correspondence: Antonio Ventosa. Tel: +349 5455 6765. Fax: +349 54628162. e-mail: ventosa@cica.es

\footnotetext{
Department of Microbiology and Parasitology, Faculty of Pharmacy, University of Seville, 41012 Seville, Spain

2 Noda Institute for Scientific Research, 399 Noda, Noda-shi, Chiba-ken 278-0037, Japan

3 Department of Microbiology and Immunology, University of Melbourne, Parkville 3052, Australia
}

\begin{abstract}
The 165 rRNA gene sequences of Halococcus saccharolyticus and Halococcus salifodinae were closely related (94.5-94.7\% similarity) to that of Halococcus morrhuae, the type species of the genus Halococcus. However, Halococcus turkmenicus was distinct from the other members of this genus, with low 165 rRNA similarities when compared to Halococcus morrhuae (88.7\%). On the basis of phylogenetic tree reconstruction, detection of signature bases and DNA-DNA hybridization data, it is proposed to transfer Halococcus turkmenicus to a novel genus, Haloterrigena, as Haloterrigena turkmenica gen. nov., comb. nov., and to accommodate Halobacterium trapanicum JCM 9743 and strain GSL-11 in the same species. On the basis of morphological, cultural and 165 rRNA sequence data, it is also proposed that the culture collection strains of Halobacterium trapanicum NCIMB 767, ATCC 43102 and JCM 8979 should be renamed as Halococcus sp.
\end{abstract}

Keywords: Haloterrigena turkmenica gen. nov., comb. nov., DNA hybridization, 16S rRNA sequence comparison, phylogeny

\section{INTRODUCTION}

Halococcus was the second genus after Halobacterium to be classified within the family Halobacteriaceae (Elazari-Volcani, 1957; Gibbons, 1974), a group of extreme halophiles which currently contains a further eight genera: Haloarcula, Haloferax, Halorubrum, Halobaculum, Natrialba, Natronobacterium, Natronococcus and Natronomonas (Kamekura et al., 1997). The 16S rRNA gene sequences of two strains of the type species, Halococcus morrhuae ATCC 17082 (Leffers \& Garret, 1984) and NRC 16008 (Kamekura $\&$ Seno, 1992), have been reported, and comparative sequence analysis has clearly shown that Halococcus represents a distinct genus within the family Halobacteriaceae (Kamekura \& Dyall-Smith, 1995). However, the complete sequences of the three other validly

Abbreviations: PG, phosphatidylglycerol; PGP-Me, phosphatidylglycerophosphate-methyl ester.

The DDBJ accession numbers for the 165 rRNA gene sequences of Halococcus saccharolyticus ATCC 49257, Halococcus salifodinae DSM 8989 and Halococcus turkmenicus VKM B-1734 are AB004876, AB004877 and AB004878, respectively. described species [Halococcus saccharolyticus (Montero et al., 1989), Halococcus turkmenicus (Zvyagintseva \& Tarasov, 1987) and Halococcus salifodinae (Denner et al., 1994)] have not been published, so phylogenetic support for their inclusion in this genus is lacking.

The aim of this study was to determine the phylogenetic relationships of these three species. For this purpose, the 16S rRNA sequences of the type strains of Halococcus saccharolyticus, Halococcus turkmenicus and Halococcus salifodinae were determined and incorporated into phylogenetic tree reconstructions.

As part of this study we also examined three other isolates, Halobacterium trapanicum NCIMB 767, ATCC 43102 and JCM 8979, which possess features similar to those of Halococcus spp.

\section{METHODS}

Bacterial strains and culture conditions. The following strains of the genus Halococcus were used in this study: Halococcus morrhuae ATCC $17082^{\mathrm{T}}$, Halococcus saccharolyticus ATCC $49257^{\mathrm{T}}$, Halococcus salifodinae DSM $8989^{\mathrm{T}}$ and Halococcus 
Table 1. Levels of DNA-DNA relatedness between Halococcus turkmenicus and other halobacterial species

The values are means of three experiments. Species for which no significant hybridization $(<11 \%)$ was detected included Halobacterium salinarum CECT 396, Haloarcula vallismortis ATCC $29715^{\mathrm{T}}$, Haloarcula marismortui ATCC $43049^{\mathrm{T}}$, Haloferax volcanii NCIMB 2012 ${ }^{\mathrm{T}}$, Haloferax mediterranei ATCC $33500^{\mathrm{T}}$ and Halorubrum distributum VKM B-1733 ${ }^{\mathrm{T}}$. ND, Not determined.

\begin{tabular}{|c|c|c|c|}
\hline \multirow[t]{2}{*}{ Source of unlabelled DNA } & \multicolumn{3}{|c|}{ Relatedness (\%) with ${ }^{3} \mathrm{H}$-labelled DNA from: } \\
\hline & VKM B-1734 ${ }^{\mathrm{T}}$ & Strain GSL-11 & ATCC $49257^{\mathrm{T}}$ \\
\hline Halococcus turkmenicus VKM B-1734 & 100 & 75 & 21 \\
\hline Strain GSL-11 & 98 & 100 & ND \\
\hline Halobacterium trapanicum JCM 9743 & 100 & 91 & 11 \\
\hline Halococcus saccharolyticus ATCC $49257^{\mathrm{T}}$ & 0 & 2 & 100 \\
\hline Halococcus morrhuae ATCC $17082^{\mathrm{T}}$ & 0 & 0 & 22 \\
\hline Halobacterium salinarum CCM 2148 & 0 & 10 & 17 \\
\hline Natrialba asiatica JCM $9576^{\mathrm{T}}$ & 10 & 48 & 0 \\
\hline Natrialba asiatica JCM 9577 & 9 & 46 & 18 \\
\hline Halobaculum gomorrense DSM $9297^{\mathrm{T}}$ & 20 & 31 & 0 \\
\hline Haloarcula hispanica ATCC $33960^{\mathrm{T}}$ & 0 & 9 & 43 \\
\hline Haloarcula japonica JCM $7785^{\mathrm{T}}$ & 27 & 23 & ND \\
\hline Haloarcula strain GN-1* & 0 & 0 & 40 \\
\hline 'Haloarcula sinaiiensis' ATCC 33800 & 0 & 0 & 26 \\
\hline Haloferax denitrificans ATCC $35960^{\mathrm{T}}$ & 0 & 1 & 13 \\
\hline Haloferax gibbonsii ATCC $33959^{\mathrm{T}}$ & 0 & 3 & 30 \\
\hline Halorubrum saccharovorum ATCC $29252^{\mathrm{T}}$ & 8 & 18 & 0 \\
\hline Halorubrum lacusprofundi DSM 5036 & 28 & 0 & 23 \\
\hline
\end{tabular}

* Strain GN-1 was obtained from Dr B. Javor.

turkmenicus VKM B-1734 ${ }^{\mathrm{T}}$. Halobacterium trapanicum JCM 8979, derived from NCIMB 767 in 1994, Halobacterium trapanicum JCM 9743, derived from NCIMB 767 in 1984 (see Discussion for details), Halobacterium trapanicum NCIMB 784, obtained from NCIMB in 1986, Halobacterium trapanicum ATCC 43102 and strain GSL-11 (24) were also included in this study. These strains were grown at $37^{\circ} \mathrm{C}$ and other strains listed in Table 1 were also grown as described previously (Kamekura \& Dyall-Smith, 1995).

Extraction of genomic DNA and determination of $\mathbf{G}+\mathbf{C}$ content. Genomic DNA was extracted from $N$-lauroylsarcosine-lysed cells of Halococcus turkmenicus, Halobacterium trapanicum JCM 9743, Halobacterium trapanicum NCIMB 784 and most of the other strains listed in Table 1 as described before (Kamekura \& Dyall-Smith, 1995). The cells of other species of the genus Halococcus and Halobacterium trapanicum JCM 8979 which do not lyse under these conditions, were treated by grinding with quartz sand, and DNA was recovered by phenol extraction and ethanol precipitation.

The percentage of $\mathrm{G}+\mathrm{C}$ of genomic DNA was determined from the midpoint value $\left(T_{\mathrm{m}}\right)$ of the thermal denaturation profile (Marmur \& Doty, 1962), using a model UV/Vis 551S spectrophotometer (Perkin-Elmer) at $260 \mathrm{~nm}$, and programmed for temperature increases of $1.0^{\circ} \mathrm{C} \mathrm{min}{ }^{-1}$. The midpoint of the thermal denaturation profiles was determined by a graphical method as described by Ferragut \& Leclerc (1976) and the $G+C$ content was calculated from this temperature using the equation of Owen \& Hill (1979) in
$0 \cdot 1 \times \mathrm{SSC}(1 \times \mathrm{SSC}$ is $0.15 \mathrm{M} \mathrm{NaCl}$ plus 0.015 trisodium citrate, $\mathrm{pH} \mathrm{7.0)}$ The $T_{\mathrm{m}}$ of reference DNA from Escherichia coli NCTC 9001 was $74.6^{\circ} \mathrm{C}$ in $0.1 \times \mathrm{SSC}$ (Owen \& Pitcher, 1985).

Sequencing of 165 rRNA genes and TLC analysis of polar lipids. Genes encoding 16S rRNA were amplified by PCR, cloned into pUC119 and sequenced (Kamekura \& DyallSmith, 1995). Final sequences of these genes were unambiguous as regions which were difficult to read on one strand were easily read by sequencing the complementary strand. Phylogenetic tree reconstructions based on these sequences and those available in the sequence databases were performed as described previously (Kamekura \& DyallSmith, 1995). Membrane lipids were extracted and determined by TLC as described previously (Kamekura \& Dyall-Smith, 1995).

Preparation of labelled DNA. DNA was labelled by using the multiprime system, a commercial kit (RPN 1601 Y; Amersham International $)$ and $\left(1^{\prime}, 2^{\prime}, 5-{ }^{3} \mathrm{H}\right) \mathrm{dCTP}$. The mean specific activity obtained with this procedure was $8.4 \times 10^{6}$ c.p.m. ( $\mu$ g DNA $)^{-1}$. The labelled DNA was denatured before hybridization by heating at $100^{\circ} \mathrm{C}$ for $5 \mathrm{~min}$ and chilled quickly on ice.

DNA-DNA hybridization experiments. DNA-DNA hybridization studies were performed by using the competition procedure of the membrane method described by Johnson (1981). Competitor DNAs were sonicated at $50 \mathrm{~W}$ for two $15 \mathrm{~s}$ bursts. Membrane filters (type HAHY; 
Millipore) containing reference DNA were placed in $5 \mathrm{ml}$ screw-cap vials which contained the labelled, sheared denatured DNA and the denatured, sheared competitor DNA. The ratio of the concentrations of competitor DNA to that of the labelled DNA was at least 150:1. The final volume was adjusted to $140 \mu \mathrm{l}$, and the reaction mixture contained $2 \times$ SSC and $30 \%$ formamide (final concentrations). The hybridization temperature ranged between 56 and $57^{\circ} \mathrm{C}$, which is within the limits of validity for the filter method (De Ley \& Tijtgat, 1970). These procedures were done in triplicate. After hybridization, the filters were washed in $2 \times \mathrm{SSC}$ at the optimum renaturation temperature. The radioactivity bound to the filters was measured with a liquid scintillation counter (Beckman Instrument) and the percentage of relatedness was calculated. At least two independent determinations were carried out for each experiment, and the results reported below are the mean values.

Nucleotide sequence accession numbers. The sequence for Halobacterium trapanicum NCIMB 784 has GenBank accession number AF027738. Accession numbers for other 16S rRNA gene sequences used in this study have been described previously (Kamekura \& Dyall-Smith, 1995; Kamekura et al., 1997).

\section{RESULTS}

\section{Morphology}

Halococcus salifodinae was coccoid, occurring in sarcina packets or irregular clusters, rarely singly or in pairs. Halococcus saccharolyticus and Halobacterium trapanicum JCM 8979 showed a morphology quite similar to Halococcus morrhuae, i.e. cocci occurring in pairs, tetrads, or sarcina packets. In contrast, Halococcus turkmenicus occurred mostly as single cells, rarely in pairs or tetrads, and was ovoid to coccoid, $1.5-2 \mu \mathrm{m}$ in diameter. Cells of two other strains of Halobacterium trapanicum NCIMB 767 and ATCC 43102 were also coccoid. Halobacterium trapanicum JCM 9743 and strain GSL-11 were rod-shaped.

\section{$\mathbf{G}+\mathbf{C}$ contents}

The $\mathrm{G}+\mathrm{C}$ contents of the DNA from Halococcus saccharolyticus ATCC 49257, Halococcus turkmenicus VKM B-1734, Halobacterium trapanicum JCM 9743 and strain GSL-11 were 64.0, 59.8, 59.2 and $60.2 \mathrm{~mol} \%$, respectively. The genomic DNA from Halococcus salifodinae was not sufficiently polymerized to measure the $\mathrm{G}+\mathrm{C}$ content.

\section{Polar lipids}

Halococcus salifodinae, Halococcus saccharolyticus and Halobacterium trapanicum JCM 8979 contained the membrane glycolipid S-DGD-1, as was previously reported by Moldoveanu et al. (1990) and Montero et al. (1989). Sonication or mechanical breakage of these cells was essential for the extraction of the membrane lipids, as is the case for Halococcus morrhuae. All of these four strains have both diphytanyl moieties (C20,
C20) and phytanyl-sesterterpanyl moieties (C20, C25) of phosphatidylglycerol (PG) and phosphatidylglycerophosphate-methyl ester (PGP-Me).

On the other hand, Halococcus turkmenicus contained S2-DGD, the characteristic glycolipid of Natrialba asiatica (Kamekura \& Dyall-Smith, 1995). Halococcus turkmenicus also had both C20, C20 and C20, C25 moieties of PG and PGP-Me, and these lipids were easily extracted from the intact cells.

\section{Nucleotide sequences of 16S rRNA genes}

The 16S rRNA genes were sequenced and compared to the previously determined sequences of Halococcus morrhuae, and other closely related species. The sequences of the genes from the four strains were complete, with lengths of 1471-1475 bp. The sequence similarity between Halococcus saccharolyticus and Halococcus salifodinae was very high $(98.9 \%)$, while those between Halococcus turkmenicus and either Halococcus saccharolyticus or Halococcus salifodinae were low $(88.9 \%)$. Similarities between Halococcus morrhuae and Halococcus saccharolyticus, and between Halococcus morrhuae and Halococcus salifodinae were 94.5 and $94.7 \%$, respectively. Using the guidelines of Devereux et al. (1990) and Fry et al. (1991), these figures suggested that Halococcus saccharolyticus and Halococcus salifodinae are members of the genus Halococcus, while Halococcus turkmenicus does not belong to this genus. The latter was most closely related to Halobacterium trapanicum JCM 9743 and strain GSL-11, with similarities of 96.0 and $95 \cdot 7 \%$, respectively.

Since cellular morphology of Halobacterium trapanicum JCM 8979 was coccoid, its 16S rRNA gene was also sequenced and found to be almost indistinguishable from the type strain of Halococcus morrhuae ( $98.9 \%$ sequence similarity).

\section{Phylogenetic tree reconstruction}

The sequences determined in the present study were aligned with those previously reported and used to reconstruct phylogenetic trees. Positions with any deletions or of uncertain alignment were removed and the remaining 1361 positions were used to construct the trees. A variety of algorithms were utilized (maximum-likelihood, maximum-parsimony, distance matrix), which gave very similar topologies except for the deepest branches, which were poorly resolved by parsimony and distance methods. A representative example is shown in Fig. 1. Since nine genera other than Halococcus and Haloterrigena were represented by type species for the sake of simplicity, topologies of other genera are taken from Kamekura \& Dyall-Smith (1995). As anticipated from the similarity values, Halococcus saccharolyticus, Halococcus salifodinae and Halobacterium trapanicum JCM 8979 clustered with Halococcus morrhuae. Halococcus turkmenicus, 


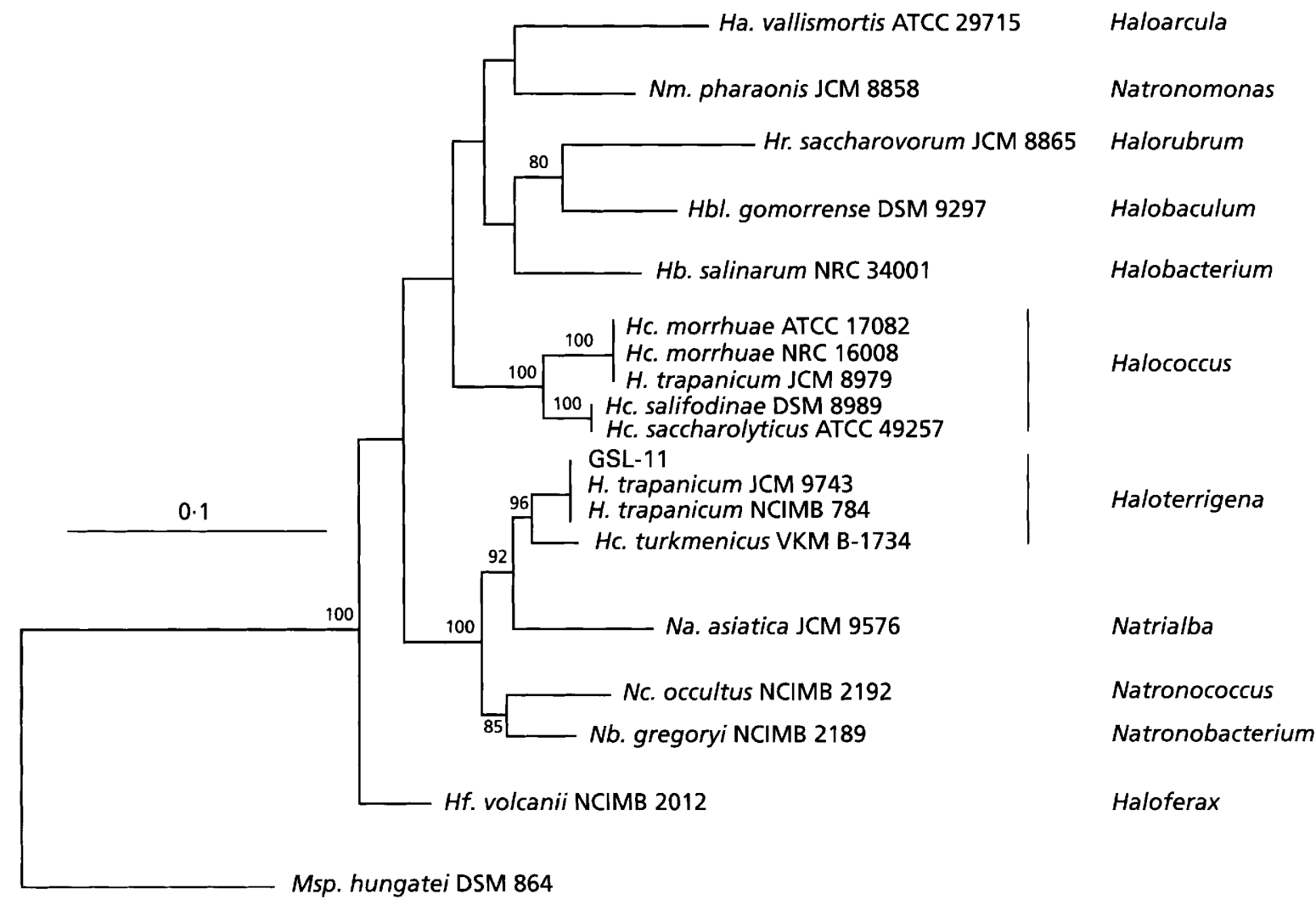

Fig. 1. Phylogenetic tree reconstruction of the Halobacteriaceae using complete $16 S$ rRNA sequences. Only the genera Halococcus and Haloterrigena contain all relevant species and strains while the other nine genera were represented by the type species. The tree shown here was produced using maximum-likelihood (ML, fastDNAml). Branches with poorly supported lengths have been collapsed. Bootstrap values (100 replicates) shown at the nodes were obtained by a distance matrix method (PHYLIP) and added to the ML tree. Only bootstrap values above $70 \%$ are shown. Except for the deepest branches, the topologies of trees derived from ML, parsimony (PAUP) and distance matrix methods were very similar. The scale bar represents 0.1 expected changes per site. Methanospirillum hungatei (accession no. M60880) was used as the outgroup.

on the other hand, was closely related to Halobacterium trapanicum JCM 9743 and strain GSL-11. Halobacterium trapanicum NCIMB 784 also clustered most closely with the Halobacterium trapanicum JCM 9743/strain GSL-11 group.

\section{Signature bases of $16 \mathrm{~S}$ rRNA genes}

Using the aligned sequences, a number of signature bases were revealed which were specific for each genus as described in a previous paper (Kamekura et al., 1997). In the genus Halococcus, 30:553T:A, 50C, $116 \mathrm{C}, 218 \mathrm{C}, 229 \mathrm{C}, 233 \mathrm{~A}, 557 \mathrm{~A}, 1289 \mathrm{C}$ and 1314:1323T:A were signature bases for the two strains of Halococcus morrhuae, Halococcus saccharolyticus, Halococcus salifodinae and Halobacterium trapanicum JCM 8979, but not for Halococcus turkmenicus. The numbering is according to the $E$. coli sequence. The strain GSL-11 and Halobacterium trapanicum JCM 9743, the most closely related strains to Halococcus turkmenicus, possessed five signature bases: $174 \mathrm{G}$, $188 \mathrm{~A}, 190(+15) \mathrm{A}(15$ bases after $E$. coli 190 ; there is 19 base gap between 190 and 191 when aligned with sequences of members of Halobacteriaceae), 209A and 610A. Of these five bases, 209A was also shared by Halococcus turkmenicus and Halobacterium trapanicum NCIMB 784, suggesting the four strains are relatively close phylogenetically.

\section{DNA-DNA hybridization studies}

As shown in Table 1, the following three strains, Halococcus turkmenicus, Halobacterium trapanicum JCM 9743 and strain GSL-11 are considered to belong to the same species since DNA-DNA relatedness among them are greater than $75 \%$.

\section{DISCUSSION}

Over the last 10 years the genus Halococcus has expanded from a relatively small and homogeneous group to one with two major divisions. On the one hand are the classical Halococcus morrhuae isolates, and on the other are two isolates with very similar $16 \mathrm{~S}$ rRNA sequences, Halococcus salifodinae and Halococcus saccharolyticus. In addition, some Halo- 
bacterium trapanicum cultures obtained from different major culture collections are really Halococcus spp., probably isolates of Halococcus morrhuae. Laboratories maintaining these particular strains should be particularly careful about confirming their identities.

Phylogenetic tree reconstructions have shown that Halococcus turkmenicus does not belong within the genus Halococcus but, along with two other isolates, Halobacterium trapanicum JCM 9743 and GSL-11, it represents a novel genus within the family Halobacteriaceae. Below we propose the name Haloterrigena. In addition, these three isolates share sufficient DNA sequence similarities to be considered as members of the same species.

The type strain of the new species should be that which was designated when the new species name was validly published. A review of the histories of all three isolates showed that Halobacterium trapanicum would appear to be the earliest described species. There have been considerable problems with different cultures of Halorubrum trapanicum and Halobacterium trapanicum, as they vary widely between different laboratories (Kamekura \& Dyall-Smith, 1995; Kamekura et al., 1997). In addition, the original type strain, NRC 34021 , is no longer available, and efforts are currently under way to designate strain NCIMB 13488 (which was derived from NRC 34021) as the neotype strain of Halorubrum trapanicum (Grant et al., 1998). According to Rule $18 \mathrm{c}$, the neotype strain will take effect 2 years from the date of publication of its proposal. The culture analysed in the present study, Halobacterium trapanicum JCM 9743, is not related to NRC 34021, the type strain of Halorubrum trapanicum (McGenity \& Grant, 1995). For these reasons, Halobacterium trapanicum JCM 9743 cannot be used as the type strain, leaving Halococcus turkmenicus as the next isolate whose name was validly published. Isolation and characterization of Halococcus turkmenicus was reported in 1987 (Zvyagintseva \& Tarasov, 1987) and the name was validly published by inclusion in Validation List no. 31 in 1989. The most recent strain to be described was strain GSL-11 (initially designated L11), which was isolated from Great Salt Lake by F. J. Post of Utah State University (Post \& Al-Harajan, 1988 ) and provided to M. Kamekura in 1984. Later it was incorporated into our taxonomic studies as L-11 (Kamekura \& Dyall-Smith, 1995; Kamekura \& Seno, 1992; Kamekura et al., 1997).

Halobacterium trapanicum JCM 9743 was originally derived from NCIMB 767 and deposited with NRC as NRC 2856 (R. Latta, personal communication). This strain was obtained from NRC in 1984 and was used under the name of Halobacterium trapanicum NCMB 767 in a TLC comparison of glycolipids from various extreme halophiles (Torreblanca et al., 1986). It has been maintained in Japan and deposited with the IAM (Institute of Applied Microbiology, University of Tokyo) in 1986 and with the JCM in 1995 , as IAM 13173 and JCM 9743, respectively.
Halobacterium trapanicum JCM 9743 and strain GSL11 have been shown to contain very similar 16S rRNA gene sequences (Kamekura \& Seno, 1993) and exactly the same polar lipid pattern (Kamekura \& DyallSmith, 1995). Halococcus turkmenicus, on the other hand, had a different glycolipid, S2-DGD, which is the characteristic lipid of Natrialba asiatica. Despite sharing the same major glycolipid, the DNA of these two strains showed only a very weak $(10 \%)$ crosshybridization. The differences in polar lipid patterns between genetically close relatives (i.e. Halococcus turkmenicus, Halobacterium trapanicum JCM 9743 and GSL-11) was unexpected, but the evidence from phylogenetic tree reconstructions and carefully performed DNA-DNA hybridization experiments clearly indicated that these strains should be considered as members of the same species.

We therefore propose to transfer Halococcus turkmenicus to Haloterrigena gen. nov. as Haloterrigena turkmenica gen. nov., comb. nov. and to accommodate Halobacterium trapanicum JCM 9743, strain GSL-11 and Halobacterium trapanicum NCIMB 784 in this species.

\section{Description of Haloterrigena gen. nov. Ventosa, Gutiérrez, Kamekura and Dyall- Smith}

Haloterrigena (Ha.lo.ter'ri.gena. Gr. n. hals, halos the sea, salt; L. fem. adj. terrigena born from the earth; M.L. fem. adj. Haloterrigena the salt born from the earth).

Gram-negative rods. Colonies are pigmented red or light pink due of the presence of C50-carotenoids. Chemo-organotrophic and aerobic. Halophilic requiring at least $2 \mathrm{M} \mathrm{NaCl} . \mathrm{G}+\mathrm{C}$ content of DNA is $59 \cdot 2-60 \cdot 2 \mathrm{~mol} \%$ ( $T_{\mathrm{m}}$ method). Membrane polar lipids are glycerol-diether analogues of PG, PGP-Me and some glycolipids. Type species is Haloterrigena turkmenica.

\section{Description of Haloterrigena turkmenica (Zvyagintseva and Tarasov 1987) comb. nov. (basonym Halococcus turkmenicus)}

Haloterrigena turkmenica (turk.men.ica. M.L. fem. gen. n. turkmenica of Turkmenia, from where the bacterium was originally isolated).

Coccoid or oval cells, $1 \cdot 5-2 \mu \mathrm{m}$ in diameter. Detailed physiological characterization is described by Zvyagintseva \& Tarasov (1987). G+C content was $59.8 \mathrm{~mol} \%$. Membrane glycolipid is S2-DGD (mannose-2,6 disulfate $1 \rightarrow 2$ glucose-glycerol diether; Kamekura et al., 1997). Both diphytanyl moieties (C20, C20) and phytanyl-sesterterpanyl moieties (C20, C25) of PG and PGP-Me are present in cell membranes. Isolated from sulfate saline soil of Turkmenia (Zvyagintseva \& Tarasov, 1987). Type strain is $4 \mathrm{k}^{\mathrm{T}}$ and has been deposited as VKM B-1734 ${ }^{\mathrm{T}}=$ NCIMB $13204^{\mathrm{T}}=$ ATCC $51198^{\mathrm{T}}$. Both strain JCM 9743 and strain GSL-11 possess at least two glycolipids, different 
from that of strain $4 \mathrm{k}^{\mathrm{T}}$, but their structures remain to be determined. Strain NCIMB 784 has been deposited as another strain of Halobacterium trapanicum. The same glycolipids of the strains JCM 9743 and GSL-11 are present, but in addition there were two other glycolipid spots detected in this strain.

\section{ACKNOWLEDGEMENTS}

We thank A. Oren for critical reading of the manuscript. Work in the laboratory of A.V. was supported by grants from the Biotech Programme of the European Commission (Generic Projects Biotechnology of Extremophiles, BIO2CT93-0273, and Extremophiles as Cell Factories, BIO4CT96-0488), the Ministerio de Educación y Ciencia, Spain (PB93-0920 and BIO97-1876-CE) and the Junta de Andalucía.

\section{REFERENCES}

De Ley, J. \& Tijtgat, R. (1970). Evaluation of membrane filter methods for DNA-DNA hybridization. Antonie Leeuwenhoek $J$ Microbiol 36, 461-474.

Denner, E. B. M., McGenity, T. J., Busse, H.-J., Grant, W. D., Wanner, G. \& Stan-Lotter, H. (1994). Halococcus salifodinae sp. nov., an archaeal isolate from an Austrian salt mine. Int J Syst Bacteriol 44, 774-780.

Devereux, R., He, S.-H., Doyle, C. L., Orkland, S., Stahl, D. A., LeGall, J. \& Whitman, W. B. (1990). Diversity and origin of Desulfovibrio species: phylogenetic definition of a family. $J$ Bacteriol 172, 3609-3619.

Elazari-Volcani, B. (1957). Genus XII. Halobacterium. In Bergey's Manual of Determinative Bacteriology, 7 th edn, pp. 207-212. Edited by R. S. Breed, E. G. D. Murray \& N. R. Smith. Baltimore: Williams \& Wilkins.

Ferragut, C. \& Leclerc, H. (1976). Etude comparative des methodes de determination du Tm de l'ADN bacterien. Ann Microbiol (Paris) 127, 223-235.

Fry, N. K., Warwick, S., Saunders, N. A. \& Embley, T. M. (1991). The use of $16 \mathrm{~S}$ ribosomal RNA analyses to investigate the phylogeny of the family Legionellaceae. J Gen Microbiol 137 , 1215-1222.

Gibbons, N. E. (1974). Family V. Halobacteriaceae. In Bergey's Manual of Determinative Bacteriology, 8th edn, pp. 269-273. Edited by R. E. Buchanan \& N. E. Gibbons. Baltimore: Williams \& Wilkins.

Grant, W. D., Oren, A. \& Ventosa, A. (1998). Proposal of strain NCIMB 13488 as neotype of Halorubrum trapanicum. Request for an Opinion. Int J Syst Bacteriol 48, 1077-1078.

Gutierrez, M. C., Ventosa, A. \& Ruiz-Berraquero, F. (1989). Deoxyribonucleic acid relatedness among species of Haloarcula and other halobacteria. Biochem Cell Biol 68, 106-110.

Johnson, J. L. (1981). Genetic characterization. In Manual of Methods for General Bacteriology, pp. 450-472. Edited by P. Gerhardt, R. G. E. Murray, R. N. Costilow, E. W. Nester, W. A. Wood, N. R. Krieg \& G. B. Phillips. Washington, DC: American Society for Microbiology.

Kamekura, M. \& Dyall-Smith, M. L. (1995). Taxonomy of the family Halobacteriaceae and the description of two new genera Halorubrobacterium and Natrialba. J Gen Appl Microbiol 41, 333-350.
Kamekura, M. \& Seno, Y. (1992). Nucleotide sequences of $16 \mathrm{~S}$ rRNA encoding genes from halophilic archaea Halococcus morrhuae NRC16008 and Haloferax mediterranei ATCC 33500. Nucleic Acids Res 20, 3517.

Kamekura, M. \& Seno, Y. (1993). Partial sequence of the gene for a serine protease from a halophilic archaeum Haloferax mediterranei R4, and nucleotide sequences of 16S rRNA encoding genes from several halophilic archaea. Experientia 49 , 503-513.

Kamekura, M., Dyall-Smith, M. L., Upasani, V., Ventosa, A. \& Kates, M. (1997). Diversity of alkaliphilic halobacteria: proposals for the transfer of Natronobacterium vacuolatum, Natronobacterium magadii, and Natronobacterium pharaonis to the genus Halorubrum, Natrialba, and Natronomonas gen. nov., respectively, as Halorubrum vacuolatum comb. nov., Natrialba magadii comb. nov., and Natronomonas pharaonis comb. nov., respectively. Int J Syst Bacteriol 47, 853-857.

Kates, M. (1993). Membrane lipids of extreme halophiles: biosynthesis, function and evolutionary significance. Experientia 49, 1027-1036.

Leffers, H. \& Garrett, R. A. (1984). The nucleotide sequence of the $16 \mathrm{~S}$ ribosomal RNA gene of the archaebacterium Halococcus morrhuae. EMBO J 3, 1613-1619.

McGenity, T. J. \& Grant, W. D. (1995). Transfer of Halobacterium saccharovorum, Halobacterium sodomense, Halobacterium trapanicum NRC34021 and Halobacterium lacusprofundi to the genus Halorubrum gen. nov., as Halorubrum saccharovorum comb.nov., Halorubrum sodomense comb. nov., Halorubrum trapanicum comb. nov., and Halorubrum lacusprofundi comb. nov. Syst Appl Microbiol 18, 237-243.

Marmur, J. \& Doty, P. (1962). Determination of the base composition of deoxyribonucleic acid from its thermal denaturation temperature. $J$ Mol Biol 5, 109-118.

Moldoveanu, N., Kates, M., Montero, C. G. \& Ventosa, A. (1990). Polar lipids of non-alkaliphilic Halococci. Biochim Biophys Acta 1046, 127-135.

Montero, C. G., Ventosa, A., Rodriguez-Valera, F., Kates, M., Moldoveanu, N. \& Ruiz-Berraquero, F. (1989). Halococcus saccharolyticus sp. nov., a new species of extremely halophilic non-alkaliphilic cocci. Syst Appl Microbiol 12, 167-171.

Owen, R. J. \& Hill, L. R. (1979). The estimation of base compositions, base pairing and genomic size of bacterial deoxyribonucleic acids. In Identification Methods for Microbiologists, 2nd edn, pp. 217-296. Edited by F. A. Skinner \& D. W. Lovelock. London: Academic Press.

Owen, R. J. \& Pitcher, D. (1985). Current methods for estimating DNA base composition and levels of DNA-DNA hybridization. In Chemical Methods in Bacterial Systematics, pp. 67-93. Edited by M. Goodfellow \& E. Minnikin. London: Academic Press.

Post, F. J. \& Al-Harajan, F. A. (1988). Surface activity of halobacteria and potential use in microbially enhanced oil recovery. Syst Appl Microbiol 11, 97-101.

Torreblanca, M., Rodriguez-Valera, F., Juez, G., Ventosa, A., Kamekura, M. \& Kates, M. (1986). Classification of nonalkaliphilic halobacteria based on numerical taxonomy and polar lipid composition, and description of Haloarcula gen. nov. and Haloferax gen. nov. Syst Appl Microbiol 8, 89-99.

Zvyagintseva, I. S. \& Tarasov, A. L. (1987). Extreme halophilic bacteria from alkaline soils. Mikrobiologiya 56, 839-844 (in Russian). 